\author{
Aneta Marek, Łukasz Marszałek
}

\title{
Obiekty militarne jako element krajobrazu kulturowego Półwyspu Helskiego
}

\begin{abstract}
Celem artykułu jest zaprezentowanie militarnych obiektów Półwyspu Helskiego, które odegrały kluczową rolę podczas obrony we wrzeniu 1939 r. Badaniem objęto dwa rejony Półwyspu Helskiego - Ośrodek Oporu Jastarnia i Rejon Umocniony Hel, w których krajobrazie zachowało się wiele fortyfikacji. W artykule wskazano lokalizację poszczególnych elementów umocnień obu obszarów oraz podano ich charakterystykę militarną i przeznaczenie. Obiekty te w późniejszym okresie były rozbudowywane na potrzeby wojska, natomiast w momencie rozformowania jednostki wojskowej straciły swoją rangę. Stały się miejscami zainteresowania miłośników militariów, co przyczyniło się do rewitalizacji obiektów i udostępnienia ich do celów kulturowych.
\end{abstract}

Słowa kluczowe: Półwysep Helski, krajobraz militarny, bunkry, fortyfikacje.

\section{Wstęp}

Półwysep Helski jest zlokalizowany w północnej części Pobrzeża Gdańskiego. Tworzy 34-kilometrową mierzeję, rozciągającą się od Kępy Swarzewskiej w kierunku południowego wschodu. Szerokość Półwyspu, oddzielającego wody Zatoki Puckiej od wód Morza Bałtyckiego, waha się od $150 \mathrm{~m}$ do $3 \mathrm{~km}$. Dzięki swojemu położeniu, ukształtowaniu oraz posiadanym walorom przyrodniczym i kulturowym stanowi dla turystów jeden z najatrakcyjniejszych zakątków Polski. Ze względu na znajdujące się tam historyczne obiekty wojskowe jest to teren szczególnie interesujący dla miłośników turystyki kulturowej, w tym historycznej i militarnej.

Celem niniejszego artykułu jest wskazanie i charakterystyka obiektów militarnych Półwyspu Helskiego w kontekście historyczno-kulturowym. Położenie Helu decydowało o jego znaczeniu militarnym i strategicznym. Końcowy odcinek Mierzei Helskiej był zmilitaryzowany. Do wczesnych lat 90. XX w. Hel był miastem częściowo zamkniętym dla turystów ze względu na znajdującą się tam siedzibę jednostki wojskowej. W 2006 r. ostatecznie ją rozformowano. W krajobrazie miasta oraz terenów przyległych zaczęto dostrzegać różnorodne obiekty militarne 
i techniczne, wykorzystywane niegdyś przez wojsko. Większość z nich na stałe wpisała się w helski kulturowy krajobraz, który należy interpretować jako świadectwo działalności człowieka, wkomponowane w różne elementy środowiska przyrodniczego. Świadectwo to jest wyrazem walki i dążeń do niepodległości, a jednocześnie obrony własnej kultury, świadomości narodowej i terytorium przez Polaków.

Problematyka związana z obiektami militarno-wojskowymi była wielokrotnie poruszana w literaturze przedmiotu. W zakresie rewitalizacji oraz wykorzystania turystycznego tematem tym zajmowali się m.in.: A. Bernaciak, R. Wiśniewska (2015), D. Chylińska (2006), M. Sołkiewicz-Kos, M. Zadworny (2010), W. Cudny, R. Rouba (2012), P. Godlewski (2013), E. Janeczko, M. Heise (2013), A. Mikos von Rohrscheidt (2009), J. Poczta (2009), D. Pszenny, E. Janeczko (2015), E. Stach (2013), Z. Wojciechowski (2010), W. Zgłobicki, J. Smyk, A. Kabała (2016).

\section{Historyczne uwarunkowania powstania obiektów militarnych}

W dniu 11 listopada 1918 r. państwo polskie po 123 latach niewoli odzyskało niepodległość. Na mocy traktatu wersalskiego, podpisanego 28 czerwca 1919 r., zakończono działania na frontach I wojny światowej. Traktat zawierał również istotne postanowienia dotyczące przebiegu granic niepodległej Polski. W myśl zawartych w nim decyzji Rzeczpospolita odzyskała dostęp do Morza Bałtyckiego na długości ponad $140 \mathrm{~km}$, w tym 76-kilometrowy odcinek linii brzegowej Półwyspu Helskiego. Dnia 10 lutego 1920 r. w Pucku generał Józef Haller dokonał uroczystego aktu zaślubin II Rzeczypospolitej z Morzem Bałtyckim (Kardas 2009).

Ze względu na strategiczne położenie Półwyspu Helskiego, doświadczenia z okresu I wojny światowej oraz stałą obawę przed konfliktem z państwem niemieckim niemal natychmiast zaczęto opracowywać plany budowy umocnień na Helu. Pierwszą z podjętych inicjatyw było rozwinięcie infrastruktury komunikacyjnej. Wzdłuż całego Półwyspu wybudowano drogę o twardej nawierzchni, a w 1921 r. ukończono szerokotorową linię kolejową. Działania te przyczyniły się do gospodarczego i turystycznego rozwoju na tym terenie, jak również w znacznym stopniu ułatwily budowę zaplanowanych fortyfikacji (Szarski 2007, Wojciechowski 2010). Generał dywizji Tadeusz Piskora, pełniący funkcję szefa Sztabu Głównego WP, 4 kwietnia 1929 r. wydał decyzję, na podstawie której na obszarze Półwyspu Helskiego wydzielono strefę najbardziej odpowiadającą celom militarnym - była to wschodnia część mierzei. Główną bazę operacyjną floty stacjonującej na Półwyspie stanowiła miejscowość Hel. Opracowane plany forty- 
fikacji zakładały także powstanie portu wojennego, kilku baterii artylerii przeciwlotniczych i nadbrzeżnych, a także budowę obiektów koszarowych, systemu łączności, schronów, magazynów oraz dalszy rozwój infrastruktury komunikacyjnej (Wojciechowski 2010). We wstępnych projektach nie przewidywano natomiast tworzenia umocnień od strony lądu (Miniewicz 1983).

\section{Rejon Umocniony Hel}

W 1931 r. zapoczątkowano prace nad budową portu wojennego, uznawanego za najważniejszy punkt umocnień. Miał on zostać wzniesiony w Helu, a wejście do portu zaplanowano od strony Zatoki Puckiej. Inwestycja nie została jednak ukończona, mimo że była realizowana nieprzerwanie do 1939 r. (Wojciechowski 2010).

Niezbędnym elementem funkcjonowania obiektów militarnych na Półwyspie były miejsca składowania amunicji oraz paliw przeznaczonych do okrętów wojskowych. Skład amunicji został zorganizowany w lesie między Helem a Borem. Prace nad przygotowaniem składu były prowadzone w latach 1933-1934. W tym czasie powstały osadzone w ziemi murowane hale, składy materiałów wybuchowych oraz żelbetowe schrony, pełniące funkcję magazynów torped. Obiekty te były bardzo dobrze zamaskowane, a każdy z nich znajdował się w pobliżu linii kolejki wąskotorowej, co miało ułatwić późniejszy transport amunicji (Wojciechowski 2010). W innym miejscu przygotowano cztery schrony do składowania amunicji artyleryjskiej, przeznaczonej do okrętów. Były to obiekty żelbetowe umieszczone w ziemi na głębokości $3 \mathrm{~m}$, starannie zamaskowane, również posiadające połączenie komunikacyjne (Wojciechowski 2010).

Niemniej ważna okazała się konieczność wzniesienia zbiorników paliwowych. Zaprojektowano cztery takie jednostki. Dwie z nich, o pojemności 1000 t, zostały zlokalizowane pomiędzy Helem a Juratą. Magazynowano w nich olej napędowy do niszczycieli. Pozostałe dwa zbiorniki o pojemności 400 t, służące do przechowywania paliwa do okrętów podwodnych, umiejscowiono w sąsiedztwie portu. Ze względu na rozpoczęcie działań wojennych w 1939 r. całkowite sfinalizowanie projektu stało się niemożliwe (Wojciechowski 2010). Do czasu wybuchu II wojny światowej zbudowano elektrownię, obiekty koszarowe, dwie studnie artezyjskie, stację i sieć wodociągową, sieć łączności przewodowej oraz zmodernizowano na potrzeby wojska sieć dróg i kolei wą̧skotorowej (Wojciechowski 2010).

W pierwszej połowie 1931 r. na Półwyspie Helskim zainstalowano pierwsze dwa działa artylerii nadbrzeżnej. Były to armaty produkcji francuskiej, kalibru $105 \mathrm{~mm}$, które zostały umiejscowione na wcześniej przygotowanych stanowiskach prowadzenia ognia. Oba działa ulokowano na cyplu helskim - pierwsze w odległości $1 \mathrm{~km}$ na południe od Góry Szwedów, drugie natomiast w odległości 1,5 km na północny zachód od pierwszej baterii. Stanowiska prócz armat posiada- 
ły dwie zbudowane $\mathrm{z}$ betonu działobitnie, które były zabezpieczone od frontu niskim przedpiersiem, a także cztery schrony amunicyjne, każdy mieszczący 200 pocisków. Dla baterii przygotowano również stanowiska zapasowe, na które w razie potrzeby można było przetransportować działa (Wojciechowski 2010).

Kolejnym etapem budowy umocnień Półwyspu było rozmieszczenie baterii średniego kalibru. Były to cztery działa kalibru 152,4 mm, mające donośność do $20 \mathrm{~km}$, wyprodukowane przez szwedzką firmę Bofors. Armaty zostały umiejscowione na czterech wybudowanych stanowiskach ogniowych, które wzniesiono w 1935 r. na wydmach helskiego cyplu, w odległości 80-90 m od siebie. Były to żelbetowe bloki o wymiarach 13,5 $\mathrm{m} \times 11,5 \mathrm{~m}$, mieszczące $\mathrm{w}$ swoim wnętrzu schron amunicyjny oraz ulokowaną na stropie działobitnię. Strop schronu miał grubość $2 \mathrm{~m}$, natomiast ściany - od 2,35 do 1,8 m. Przed każdym stanowiskiem utworzono płytę detonacyjną o szerokości $3,8 \mathrm{~m}$ i grubości $0,4 \mathrm{~m}$. Miała ona zabezpieczać schron przed wybuchem bomb oraz pocisków w pobliżu.

Dnia 25 czerwca 1935 r. decyzją ministra spraw wojskowych utworzono na Helu dywizjon artylerii nadbrzeżnej, składający się z 16 oficerów, 349 podoficerów i szeregowych, a także dwóch pracowników cywilnych (Wojciechowski 2010). W późniejszym czasie, 1 stycznia 1937 r., bateria otrzymała imię kmdr. ppor. Heliodora Laskowskiego. Było to pośmiertne uhonorowanie człowieka, który znacząco przyczynił się do powstania i zorganizowania artylerii nadbrzeżnej na Półwyspie (Szarski 2007).

W planach budowy umocnień na Półwyspie Helskim istotne miejsce zajmowała również budowa dział artylerii przeciwlotniczej. Zaprojektowano trzy baterie służące do prowadzenia ostrzału celów powietrznych oraz morskich. Rozlokowano je w następujących miejscach: pierwsza $\mathrm{z}$ nich powstała w pobliżu latarni morskiej w Helu, druga - na północ od portu wojennego, a kolejna - w okolicach przystanku kolei wąskotorowej Bór. W żelbetonowych obiektach mieściły się składy 1000 sztuk amunicji, z kolei na stropie umieszczono działobitnie $\mathrm{z}$ armatami typu schneider, kalibru $75 \mathrm{~mm}$. Budynki te miały blaszane zadaszenie i były starannie zamaskowane. W sąsiedztwie drugiej z wymienionych baterii w $1936 \mathrm{r}$. wzniesiono wieżę obserwacyjną dla dowódcy powstałej artylerii przeciwlotniczej. Projekt zakładał również budowę - w bliskiej odległości od wieży - przeznaczonego dla dowódcy schronu, stanowiącego ośrodek kierowania ogniem i wyposażonego $\mathrm{w}$ centralę telefoniczną oraz radiostację. Zgodnie z zarządzeniem wprowadzonym w 1935 r. przez szefa Kierownictwa Marynarki Wojennej, kadm. Jerzego Świrskiego, na Helu utworzono dywizjon artylerii przeciwlotniczej składający się z: „13 oficerów, 57 podoficerów zawodowych i nadterminowych oraz 263 podoficerów i szeregowych służby zasadniczej” (Wojciechowski 2010, s. 254). 
Wobec stałego rozwoju infrastruktury militarnej na Półwyspie Helskim w lutym 1935 r. kadm. Jerzy Świrski postanowił powołać do życia Dowództwo Odcinka Wybrzeża Morskiego, któremu podlegał pas wybrzeża od Władysławowa (daw. Wielka Wieś) do Helu (Wojciechowski 2010). Natomiast 21 sierpnia 1936 r., zgodnie z dekretem Prezydenta RP Ignacego Mościckiego, utworzono Rejon Umocniony Hel, który swoim zasięgiem obejmował tereny od Juraty aż do końca Półwyspu (Dekret Prezydenta Rzeczpospolitej... 1936). Obszar ten przeszedł pod administrację wojska, 8 marca 1937 r. zaś Rada Ministrów uchwaliła rozporządzenie dotyczące dekretu, na mocy którego na wskazanym obszarze wprowadzono znaczne ograniczenia dotyczące m.in.: budowy obiektów, dokonywania zmian $w$ istniejącej infrastrukturze, prowadzenia prac mogących przyczynić się do zmiany ukształtowania terenu, fotografowania, przebywania osób postronnych na wschód od Juraty. Dostęp przewidziany był wyłącznie dla obywateli RP posiadających specjalnie przygotowane przepustki lub mogących okazać dokumenty wojskowe (Wojciechowski 2010).

\section{Ośrodek Oporu Jastarnia}

Jak wcześniej wspomniano, w pierwotnym planie fortyfikacji Półwyspu Helskiego nie przewidziano budowy umocnień od strony lądu. Sytuacja uległa zmianie po wprowadzeniu Rejonu Umocnionego Hel. Głównym inicjatorem utworzenia linii fortyfikacji broniących dostępu do głównej bazy floty w Helu był gen. bryg. Władysław Bortnowski. Dzięki jego staraniom w latach 1936-1942 wprowadzono istotne zmiany $\mathrm{w}$ projekcie rozbudowy marynarki wojennej, zakładające m.in. podjęcie prac nad stworzeniem obiektów obrony przeciwdesantowej na Półwyspie. W myśl powstałych planów umocnienia miały być wzniesione w okolicach Jastarni do 1940 r. Sprawa nabrała tempa w kwietniu 1939 r., kiedy wojska niemieckie zajęły Kłajpedę. Zaplanowano utworzenie dwóch linii fortyfikacji, tworzących Ośrodek Oporu Jastarnia, odcinając tym samym dostęp do Rejonu Umocnionego Hel od strony lądu (Miniewicz 1983). Pierwsza linia oporu składała się z czterech schronów bojowych, nazwanych w późniejszym czasie: Sokół, Sabala, Saragossa oraz Sęp (ryc. 1). Została ona ulokowana ok. 3,5 km na zachód od Jastarni. Umocnienia rozmieszczono w poprzek Półwyspu, w miejscu gdzie jego szerokość wynosi ok. $500 \mathrm{~m}$. Druga linia miała powstać za pierwszą, w odległości $200 \mathrm{~m}$ od niej. Prace budowlane rozpoczęto 15 maja 1939 r. Zakładano, ze zostaną one zakończone 15 września tego samego roku (Wojciechowski 2010).

Ciężki schron bojowy Sokół zbudowano tuż nad brzegiem Zatoki Puckiej, ok. $10 \mathrm{~m}$ od brzegu oraz $100 \mathrm{~m}$ od przebiegającej przez Półwysep drogi. Jest to obiekt jednokondygnacyjny z żelbetonu, mający wymiary 12,5 x 12,65 m, nieregularny 


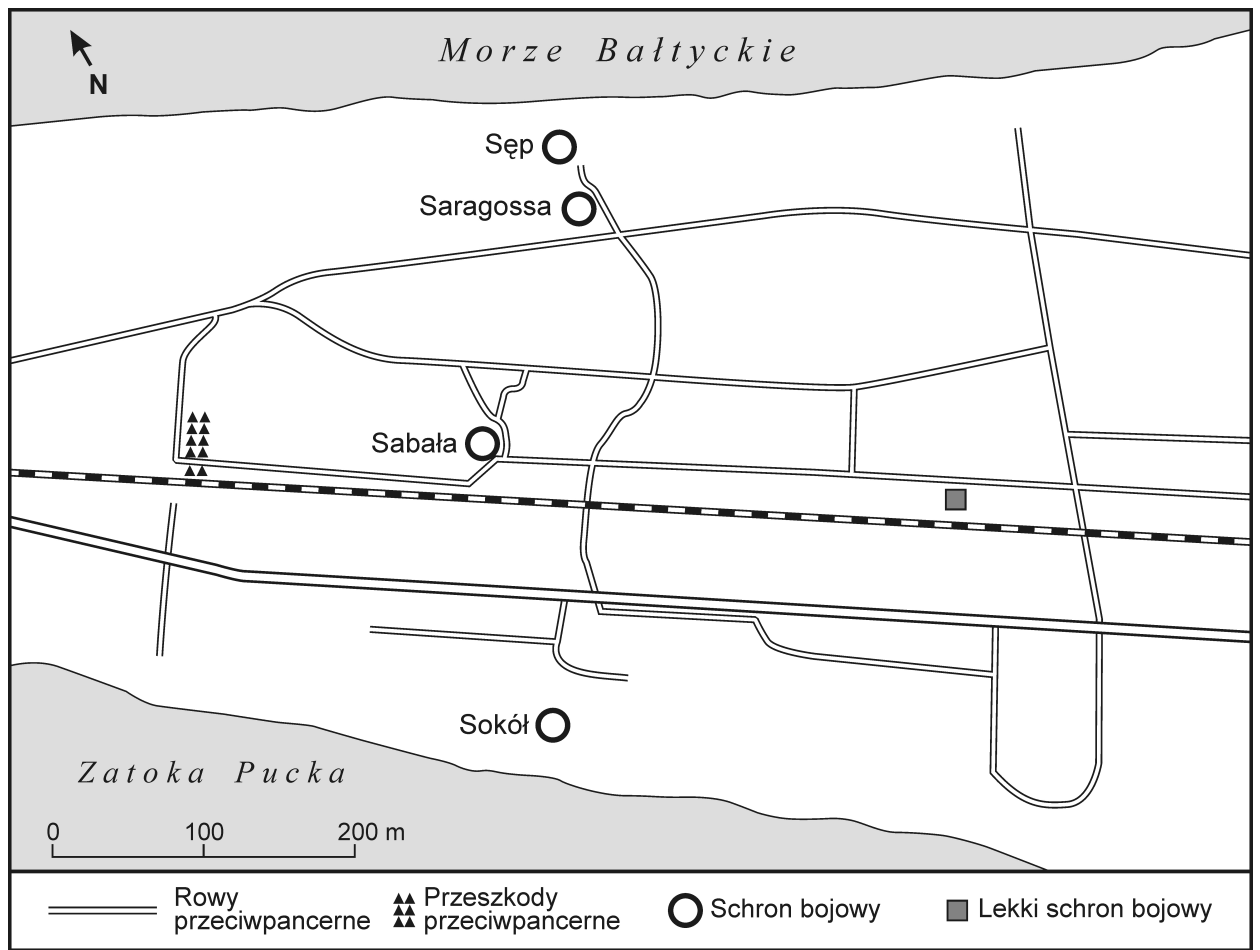

Ryc. 1. Rozmieszczenie schronów bojowych na terenie Jastarni Źródło: opracowanie własne

kształt oraz zróżnicowaną grubość ścian zewnętrznych - od 1,25 do 2,2 m (przy kopule pancernej). Ze względu na swoją rolę i zadania schron wewnątrz został bardzo rozbudowany. Znajdują się w nim:

- strzelnica tradytorowa (do prowadzenia ognia bocznego) na ciężki karabin maszynowy (ckm);

- pomieszczenie przeznaczone do wypoczynku załogi schronu;

- komora okrągła z szafkami na granaty;

- strzelnice do ręcznego karabinu maszynowego (rkm);

- komora amunicyjna;

- miejsce na urządzenia filtrowentylacyjne;

- korytarz, w którym mieściła się drużyna żołnierzy (do 15 osób);

- komory (amunicyjna, odpylająca, gazoszczelna).

W obiekcie znajdowało się następujące uzbrojenie: dwa ckm-y wz. 30 browning, dwa rkm-y wz. 28 browning, dwie wyrzutnie ręcznych granatów oraz reflektor o średnicy $60 \mathrm{~cm}$ (Miniewicz 1983). 
Kolejnym i zarazem największym spośród obiektów pierwszej linii fortyfikacji jest schron Sabała. Znajduje się on w lesie w odległości ok. $30 \mathrm{~m}$ od linii kolejowej i $150 \mathrm{~m}$ od drogi. Podobnie jak Sokół jest to budowla jednokondygnacyjna, żelbetowa, o wymiarach 15,60 x 15,30 m, o grubości ścian zewnętrznych od 2,5 do $1,25 \mathrm{~m}$. Sabała był schronem przeznaczonym dla dowództwa ośrodka oporu i odwodów. Układ pomieszczeń wewnątrz przedstawia się następująco:

- dwie izby bojowe na ckm-y (strzelnica tradytorowa);

- dwa pomieszczenia dla załogi, dwa korytarze;

- dwie komory pod kopułami pancernymi;

- pomieszczenie dla dowódcy;

- pomieszczenie dla centrali telefonicznej;

- niewielka izba bojowa;

- komora amunicyjna;

- miejsce na urządzenia filtrowentylacyjne;

- komory (gazoszczelna i czerpni powietrza).

Pod względem uzbrojenia w Sabale były: trzy ckm-y wz. 30, dwa rkm-y wz. 28, cztery ręczne wyrzutnie granatów oraz reflektor. Pierwotnie w planach budowy schronu zaprojektowano dwie kopuły pancerne. Niestety do rozpoczęcia działań wojennych ukończono tylko jedną, w której zainstalowano ckm. Druga, biorąc pod uwagę wykonaną pod nią konstrukcję, miała być przeznaczona do znacznie cięższej broni - prawdopodobnie działka fortecznego przeciwpancernego (Miniewicz 1983).

Następnym ciężkim schronem bojowym jest Saragossa. Obiekt o wymiarach 11,85 x 12,35 m zlokalizowano w odległości ok. 200 m od Sabały, na krańcu obszaru wydmowego, tuż przy plaży. Technicznie budowla wykonana jest podobnie jak wcześniej przedstawione fortyfikacje. Spośród innych położonych w tej linii oporu wyróżnia ją niespotykana w trzech pozostałych strzelnica do ognia czołowego. Liczba i przeznaczenie znajdujących się w niej pomieszczeń oraz wyposażenie ogniowe są identyczne jak w schronie Sokół (Miniewicz 1983).

Czwartym i zarazem ostatnim obiektem pierwszej linii fortyfikacji Ośrodka Oporu Jastarnia jest ciężki schron bojowy Sęp, wzniesiony na plaży w bliskim sąsiedztwie Saragossy. Żelbetowa konstrukcja schronu ma wymiary 15,30 x 12,75 m, grubość jej ścian dochodzi do 3,30 m (przy kopułach). Układ pomieszczeń wewnątrz obiektu prezentuje się następująco:

- pomieszczenie ze strzelnicą tradytorową na ckm;

- miejsce wypoczynku dla załogi;

- dwie komory pod kopułą, w których znajdują się szafki na granaty; 
- izba ze strzelnicą rkm, zawierająca wyjście awaryjne;

- korytarz, w którego wnętrzu mieści się drużyna żołnierzy;

- magazyn amunicyjny i komora na moździerz;

- izba dla urządzeń filtrowentylacyjnych;

- komory (gazoszczelna oraz czerpni powietrza).

Wyposażenie bojowe schronu stanowiły: dwa ckm-y, jeden rkm, jeden moździerz $81 \mathrm{~mm}$, dwie ręczne wyrzutnie granatów, reflektor. Podobnie jak w przypadku Sabały, tak i w schronie Sęp zaprojektowano kopułę pod działko ppanc. $37 \mathrm{~mm}$, niestety ze względu na wybuch wojny nie udało się ukończyć prac budowlanych. W efekcie nie zdołano nawet skonstruować stropu nad komorą znajdującą się pod zaplanowaną kopułą (Miniewicz 1983).

Nagła agresja III Rzeszy na Polskę uniemożliwiła również kontynuowanie prac przy budowie drugiej zaplanowanej linii oporu. W efekcie powstał tylko jeden lekki schron bojowy o ogniu jednobocznym, umiejscowiony w pobliżu sieci kolejowej, ok. $300 \mathrm{~m}$ za pierwszymi fortyfikacjami. Grubość ścian waha się tutaj od 0,40 do $1,20 \mathrm{~m}$. Jest to obiekt $\mathrm{z}$ jednym pomieszczeniem przeznaczonym na strzelnicę ckm. W przypadku kolejnych schronów przygotowano wyłącznie fundamenty, których pozostałości można jeszcze zidentyfikować w terenie (Miniewicz 1983).

Całość Ośrodka Oporu Jastarnia dopełniały także skonstruowane w terenie przeszkody bierne. Należały do nich m.in.: rowy strzeleckie, posiadające stanowiska polowe dla broni maszynowej, przesieki w lasach, przeszkody z drutu kolczastego oraz rozlokowane w niektórych miejscach miny (Miniewicz 1983).

\section{Obiekty niemieckie}

W dniu 1 września 1939 r. przebywający w gdańskim porcie pancernik Schleswig-Holstein rozpoczął ostrzał Wojskowej Składnicy Tranzytowej na Westerplatte. Jak powszechnie wiadomo, był to zaplanowany atak wojsk niemieckich na Polskę, który zapoczątkował II wojnę światową. Na skutek dobrze zorganizowanych działań wojennych wroga w niedługim czasie obszar Półwyspu Helskiego został ocięty od pozostałej części kraju. Wzniesione na Helu obiekty militarne, fortyfikacje i umocnienia doskonale spełniały swoją funkcję w czasie działań wojennych. Pomimo przeważających sił III Rzeszy przypuszczającej ataki z morza, lądu i powietrza jednostki zgromadzone na terenie Rejonu Umocnionego Hel dzielnie stawiały opór, broniąc się nieustannie do 2 października 1939 r., kiedy to po kapitulacji Warszawy i Modlina poddano Półwysep (Wojciechowski 2010, Szarski 2007).

Niemcy, świadomi strategicznego znaczenia opisywanego w niniejszym artykule obszaru, tuż po jego zdobyciu przejęli istniejące polskie systemy umocnień, dostosowując je do swoich potrzeb. Jednocześnie rozpoczęli prace mające na celu 
wzmocnienie potencjału militarnego, m.in. zamontowano trzydziałową baterię Schleswig-Holstein (Kardas 2011). Została ona ulokowana w odległości ok. 1 km w kierunku północnym od Helu. Składała się z trzech stanowisk ogniowych o wymiarach 64 x 39 m, wykonanych z konstrukcji żelbetowych. Każde stanowisko posiadało:

- działo kalibru $406 \mathrm{~mm}$, umieszczone w wieży pancernej;

- komorę amunicyjną;

- pomieszczenie o przeznaczeniu koszarowo-technicznym.

Wszystkie stanowiska zostały starannie zamaskowane. Zasięg baterii dochodził do blisko $56 \mathrm{~km}$. Dzięki temu miała ona skutecznie bronić dostępu do wód Zatoki Gdańskiej. W pobliżu obiektów umiejscowiono także dwa działka artylerii przeciwlotniczej kalibru $20 \mathrm{~mm}$. Całość dopełniała zlokalizowana w pobliżu wód Zatoki Gdańskiej wieża kierowania ogniem, mająca dziewięć kondygnacji. Wyposażona była w dalocelownik, dalmierz oraz centralę artyleryjską. Jako że sytuacja na froncie wschodnim była stosunkowo bezpieczna, postanowiono przenieść działa do Francji w okolice miejscowości Calais, by wzmocnić militarnie wał atlantycki. Wybudowane obiekty wykorzystano natomiast jako jednostki koszarowe dla żoknierzy artylerii przeciwlotniczej, która zaczęła rozwijać się bardziej dynamicznie ze względu na obawę przed nalotami wojsk alianckich. W tym celu na Półwyspie rozlokowano m.in. schrony dla stanowisk kierowania ogniem baterii przeciwlotniczej, mające konstrukcję żelbetonową. Pozostałości tych budynków istnieją do dzisiaj. Jeden z nich aktualnie pełni funkcję punktu obserwacji pożarowej (Wojciechowski 2010).

W czasie II wojny światowej Niemcy zorganizowali w Gdyni oraz Babich Dołach posiadające niezależne lotnisko Torpedowe Zakłady Doświadczalne, w których zajmowano się montażem i przeprowadzaniem prób torped lotniczych. Prób dokonywano w wodach Zatoki Gdańskiej. W tym celu wzniesiono na wodzie trzy wykonane $\mathrm{z}$ betonu punkty wykorzystywane do obserwacji ruchu torped. Zostały one rozmieszczone w następujący sposób: jeden w pobliżu Juraty, a dwa pozostałe w okolicach Helu-Boru. Przetrwały one do dnia dzisiejszego (Wojciechowski 2010).

Basen Zatoki Gdańskiej podczas II wojny światowej był bardzo cenny dla państwa niemieckiego. Oprócz wymienionych działań w funkcjonujących na tym terenie bazach wojskowych odbywały się m.in. poligony ćwiczebne oraz szkolenia żołnierzy artylerzystów i marynarzy okrętów podwodnych. Ponadto testowano tam prototypy tajnych broni i radarów oraz napędy łodzi podwodnych U-boot i torped. Przez cały okres trwania działań wojennych stale umacniano Półwysep. Wznoszono stacje radarowe, konstruowano przeszkody polowe, rowy przeciwpancerne, przekopy, zaporę przeciwczołgową, utworzono lotnisko polowe. 
To wszystko sprawiło, że ten teren był bardzo dobrze umocniony i przygotowany do obrony przed atakiem nieprzyjaciela. Oblężeni przez wojska radzieckie w 1945 r. Niemcy stacjonujący na Półwyspie Helskim skutecznie odpierali trwające kilka tygodni ataki. Poddali się 9 maja tego roku (Wojciechowski 2010, Szarski 2007).

\section{Obiekty militarne Pólwyspu Helskiego w latach 1945-2016}

Po zakończeniu wojny umocnienia znajdujące się na Półwyspie Helskim wciąż miały bardzo duże znaczenie strategiczne i militarne dla państwa. Szczególnie w czasie oziębienia stosunków międzypaństwowych na linii USA-Rosja (tzw. zimna woja), postanowiono jeszcze bardziej dozbroić ten obszar. Wykorzystując istniejące obiekty baterii Laskowskiego, utworzono 13. Baterię Artylerii Stałej (BAS). Wyeksploatowane w czasie działań wojennych działa firmy Bofors zastąpiono radzieckimi działami B-13 kalibru $130 \mathrm{~mm}$. W latach 50. XX w. w pobliżu wejścia do portu rybackiego w Helu wzniesiono konstrukcję, należącą do kolejnej BAS, której nadano numer 27. Główną funkcją tej jednostki było bronienie wód Zatoki Gdańskiej przed atakiem kutrów torpedowych, a także zwalczanie sił desantowych oraz obrona przeciwlotnicza. W latach 1955-1958 wybudowano obiekty należące do nowo powstałej i największej pod względem uzbrojenia baterii artylerii nadbrzeżnej - 3 BAS. Została ona umiejscowiona w rejonie Helu-Boru. W pobliżu Góry Szwedów powstały zaś obiekty należące do Batalionowego Rejonu Umocnionego (BRU nr 2), który miał odpierać desanty morskie. Dodatkowo rozlokowano tam stanowisko baterii artylerii przeciwlotniczej, której pozostałości można tam zobaczyć do dzisiaj. W latach 60. i 70. XX w. na Półwyspie powstały również stanowiska $\mathrm{z}$ bronią rakietową, $\mathrm{w}$ postaci dwóch dywizjonów rakietowych Wojsk Obrony Powietrznej Kraju. Pierwszy z nich znajdował się na północny wschód od Helu, a drugi na południowy zachód od Helu-Boru. Prócz tego na Helu intensywnie rozbudowywano bazę towarzyszącą, w której skład wchodziły m.in.: ośrodek sprawności fizycznej, trzy strzelnice, kotłownia, elektrownia, magazyny, łamacze fal (Wojciechowski 2010). W tym okresie Półwysep Helski był jedną z najlepiej uzbrojonych i strzeżonych baz wojskowych na terenie Polski. W związku ze wzrostem znaczenia broni rakietowej w 1974 r. rozwiązano wszystkie baterie artylerii stałej. W późniejszych latach Hel stopniowo tracił swoje znaczenie militarne. Oddziały wojsk były przenoszone, a obiekty bazy systematycznie pustoszały. Pozostawione bez opieki, powoli popadały w ruinę. Istniejące działa były demontowane, a następnie złomowane. 
Niektóre z niszczejących obiektów usiłowano zagospodarować. Dla przykładu na stanowisku Anton zainstalowano centralę łączności Polskiej Marynarki Wojennej, w stanowisku Bruno urządzono wojskową strzelnicę, w stanowisku Cezar utworzono magazyn ziemiopłodów ${ }^{1}$. W sytuacji stałego niszczenia istniejących umocnień członkowie Stowarzyszenia „Przyjaciele Helu” dzięki swoim staraniom, mającym na celu zaprzestanie dalszej destrukcji fortyfikacji, 1 maja 2006 r. utworzyli w Helu Muzeum Obrony Wybrzeża (MOW). Niektóre obiekty przeszły rewitalizację i zyskały nowego opiekuna. Dzięki temu Półwysep stał się jedną z najciekawszych atrakcji turystycznych w Polsce (Wojciechowski 2010, Szarski 2007).

\section{Pólwysep Helski jako skansen militarny}

Na Półwyspie Helskim obiekty militarne zostały uznane za prawnie chronione. W dniu 15 czerwca 1999 r. do rejestru zabytków, pod numerem 1693, wpisano obiekty zbudowane w latach 1931-1939 przez Polską Marynarkę Wojenną, położone na terenie Rejonu Umocnionego Hel (bateria $\mathrm{nr}$ 31, bateria $\mathrm{nr} 21$, bateria $\mathrm{nr} 33$, bateria nr 22, bateria nr 32, bateria nr 23) oraz Ośrodka Oporu Jastarnia (schrony: Sęp, Saragossa, Sabała, Sokół). Wśród obiektów chronionych Półwyspu Helskiego znalazł się również zespół fortyfikacji niemieckich z lat 1939-1940, bateria Schlezwig-Holstein, składająca się z trzech stanowisk ogniowych, wieży kierowania ogniem i dwóch magazynów amunicyjnych.

Jak już wspomniano, 1 maja 2006 r. powołano w Helu Muzeum Obrony Wybrzeża. Sukcesywnie prowadzono prace remontowo-budowlane i instalacyjne, które pozwoliłyby na wyeksponowanie obiektów militarnych. W skład kompleksu MOW wchodzi obecnie sześć obiektów (ryc. 2).

Pierwszym obiektem, który poddano rewitalizacji, było stanowisko artyleryjskie B2 Bruno. W jego pomieszczeniach odbywają się wystawy stałe i tymczasowe, znajdują się tam również: sala telewizyjna, magazyny, pracownie. Odtworzono izbę podoficerską, salę kmdr. Zbigniewa Przybyszewskiego, gabinet Roentgena $\mathrm{z}$ Pucka, niemiecki gabinet zabiegowy oraz gabinet dowódcy armaty B2 bat. Schleswig-Holstein. Prezentowane są tam następujące wystawy: „Wielkie tragedie morskie 1945”, „Morski Dywizjon Lotniczy w Pucku”, „Wojna i medycyna”, „Historia baterii 406 mm Schleswig-Holstein”, „Zbrojownia”, „Granaty”, „32 dni obrony Helu”, „IV Batalion KOP HEL”.

Wokół stanowiska B2 został utworzony skansen, na którego terenie prezentwane są: armaty różnych typów, miny morskie, elementy trałów przeciwtorpedowych

\footnotetext{
${ }^{1} \mathrm{http}: / /$ www.helmuzeum.pl/muzeum/historia-mow\#mow (26.11.2017).
} 


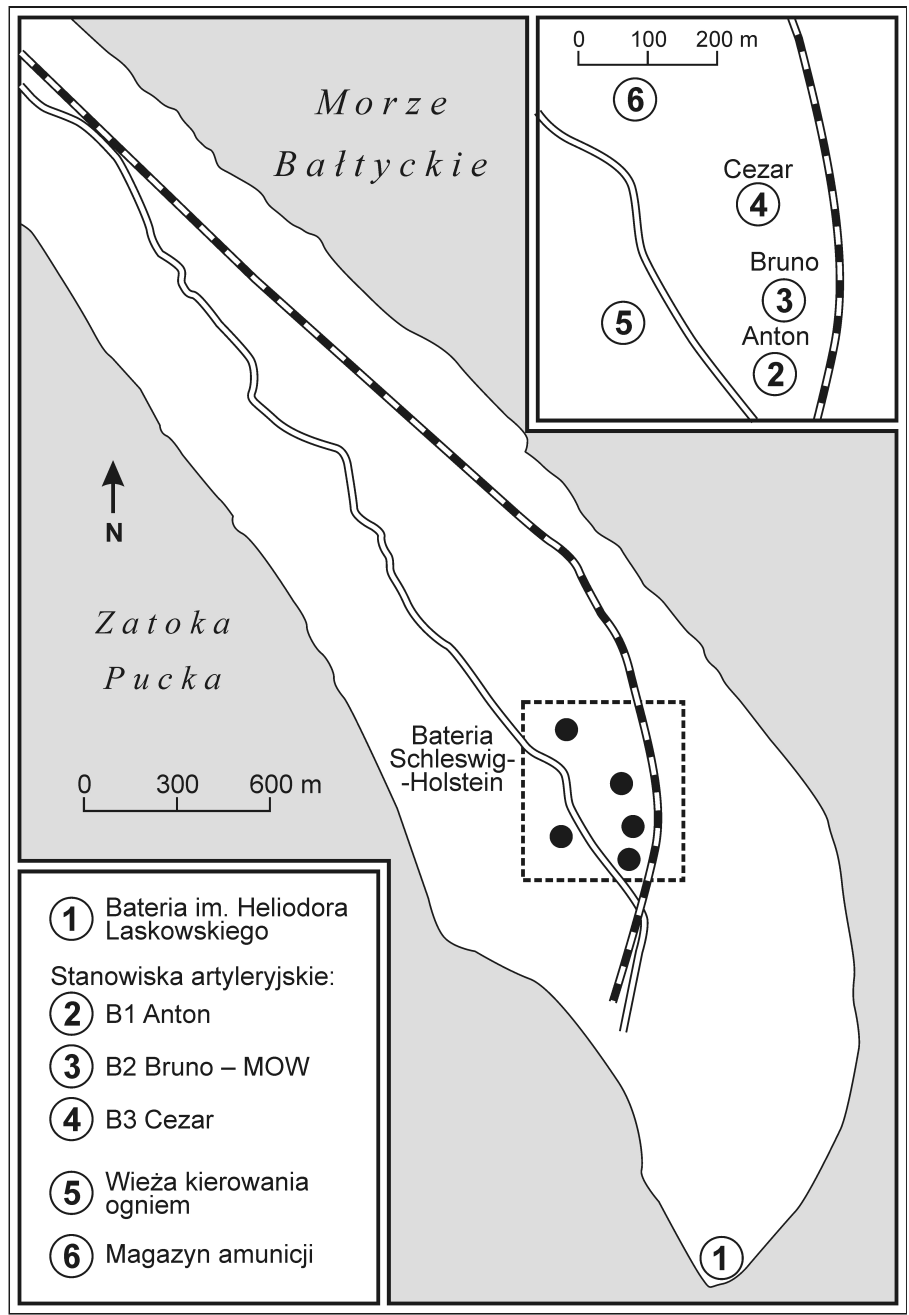

Ryc. 2. Rozmieszczenie obiektów militarnych wchodzących w skład Muzeum Obrony Wybrzeża w Helu Źródło: opracowanie własne

wych, torpedy i wyrzutnie torpedowe, łodzie i szalupy, tabor kolei wąskotorowej, samochody strażackie, samochód „sanitarka”.

Następnym obiektem, który odrestaurowano, była bateria nr $31 \mathrm{im}$. Heliodora Laskowskiego (ryc. 3). Obiekt ten udostępniono turystom w 2007 r. W podziemiach stanowiska prezentowana jest armata B-13. Została tam również urządzona wystawa upamiętniająca dowódcę baterii z 1939 r. - kpt. Zbigniewa Przybyszewskiego. 


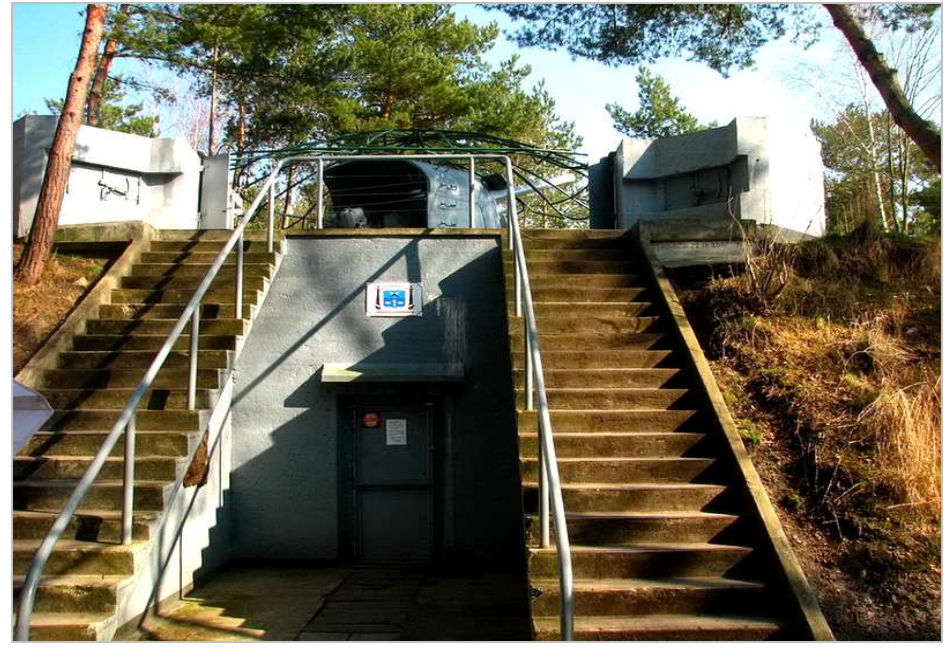

Ryc. 3. Bateria nr 31 im. Heliodora Laskowskiego Źródło: fot. A. Marek

Kolejnym obiektem administrowanym przez MOW jest wieża kierowania ogniem. W jej kopule zamontowano dalmierz optyczny o bazie $10,5 \mathrm{~m}$. Na szczycie wieży znajduje się taras widokowy. W czasie II wojny światowej dolna część budynku stanowiła centrum dowodzenia baterii Schleswig-Holstein. Obecnie dolne pomieszczenia pełnią funkcję ekspozycji muzealnej, w której prezentowane są następujące wystawy: „Polski wywiad w czasie II wojny światowej”, „Ciekawostki najcięższej artylerii - historia największych armat świata", wystawa sprzętu łączności wojskowej, wystawa modeli pojazdów pancernych II wojny światowej, wystawa poświęcona kapitanowi Karolowi Olgierdowi Borchardtowi (w opisywanym obiekcie m.in. odtworzono jego mieszkanie). We wnętrzu wieży znajduje się mapa poglądowa Półwyspu Helskiego. Podczas zwiedzania istnieje możliwość zapoznania się z zasadami pracy urządzeń dalocelownika i dalmierza.

W skład kompleksu MOW wchodzi również magazyn amunicji poniemieckiej baterii Schleswig-Holstein. Obecnie mieści się w nim Muzeum Kolei Helskich, które otworzono w 2013 r. Wystawy nawiązują do historii kolejnictwa Półwyspu Helskiego. Uwagę zwraca linia szerokotorowa, którą zbudowano w 1921 r., oraz sieć wojskowych kolejek wąskotorowych stworzonych w latach 20. XX w., a następnie rozbudowanych podczas II wojny światowej. Wokół obiektu znajduje się ekspozycja, na której zaprezentowano elementy taboru kolejowego.

Stanowisko B1 Anton otworzono dla odwiedzających 30 maja 2015 r. Pierwotnie funkcjonowało ono jako Muzeum Przyrodniczo-Etnograficzne, natomiast 6 maja 2016 r. rozpoczęło tam swoją działalność Muzeum Helu. Wewnątrz sta- 
nowiska artyleryjskiego B-1 Anton znajdują się wystawy etnograficzne, przedstawiające życie rybaków, stolarzy, kowali. Mieści się tam kolekcja sprzętów codziennego użytku, a także muszli, bursztynów i minerałów. Wokół stanowiska B1 utworzono w 2015 r. ogródek przyrodniczy, w którym rosną różne gatunki drzew, krzewów i roślin zielnych.

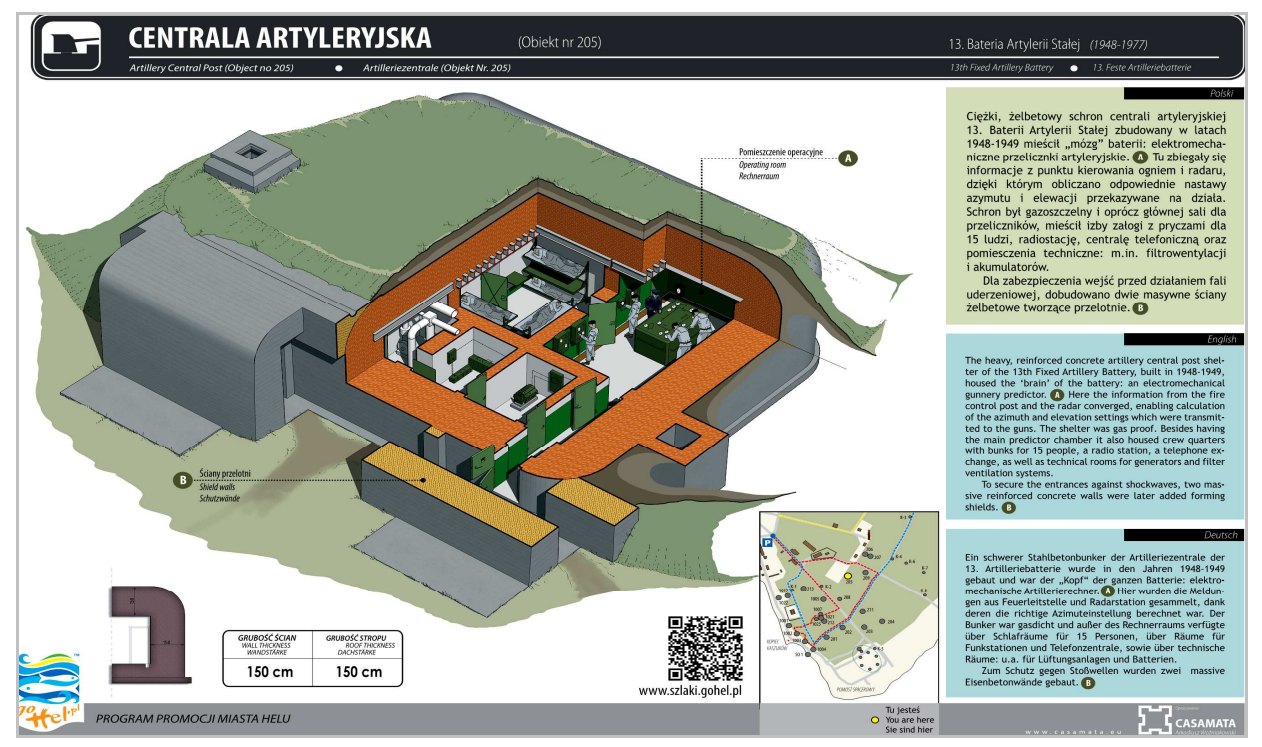

Ryc. 4. Przykład tablicy informacyjnej na szlaku Wokół helskich fortyfikacji Źródło: http://www.gohel.pl/strona-2525-fortyfikacje_cypla_helskiego.html

Stanowisko artyleryjskie B-3 Cezar jest niedostępne dla zwiedzających. Jedynie podczas Nocy Muzeów wewnątrz obiektu odbywają się rekonstrukcje wojskowe, podczas których prezentowane są różne wydarzenia z okresu II wojny światowej.

Dla podkreślenia walorów militarnych Helu utworzono system szlaków fortyfikacjnych. W jego skład wchodzi dziewięć tras, które są oznaczone za pomocą trójkąta (w kolorze właściwym dla danego szlaku) umieszczonego na białym prostokącie. Do głównego szlaku, oznaczonego kolorem niebieskim, dociera osiem ścieżek. Dodatkowo na niektórych szlakach znajdują się tablice dydaktyczne (ryc. 4), informujące o konstrukcji i wykorzystaniu poszczególnych obiektów.

Efektownie prezentują się obiekty fortyfikacyjne Jastarni. W 2005 r. został tam założony Skansen Fortyfikacji II Rzeczypospolitej im. Kontradmirała Włodzimierza Steyera. Na omawianym obszarze znajdują się cztery ciężkie schrony bojowe i jeden lekki, a także przeszkody przeciwpancerne i przeciwpiechotne oraz fortyfi- 
kacje polowe. Zostały one odrestaurowane i połączone dwiema ścieżkami dydaktycznymi. Funkcję muzealną pełni jedynie schron Sabała, w którym prezentowana jest ekspozycja związana $\mathrm{z}$ wyposażeniem i funkcjonowaniem fortyfikacji II Rzeczypospolitej. Ciekawie wpisują się w środowisko przyrodnicze dwa obiekty - schron Sęp, usytuowany na plaży (tj. od strony Morza Bałtyckiego) (ryc. 5), oraz schron Sokół, który zabezpieczał pozycję od strony Zatoki Puckiej.

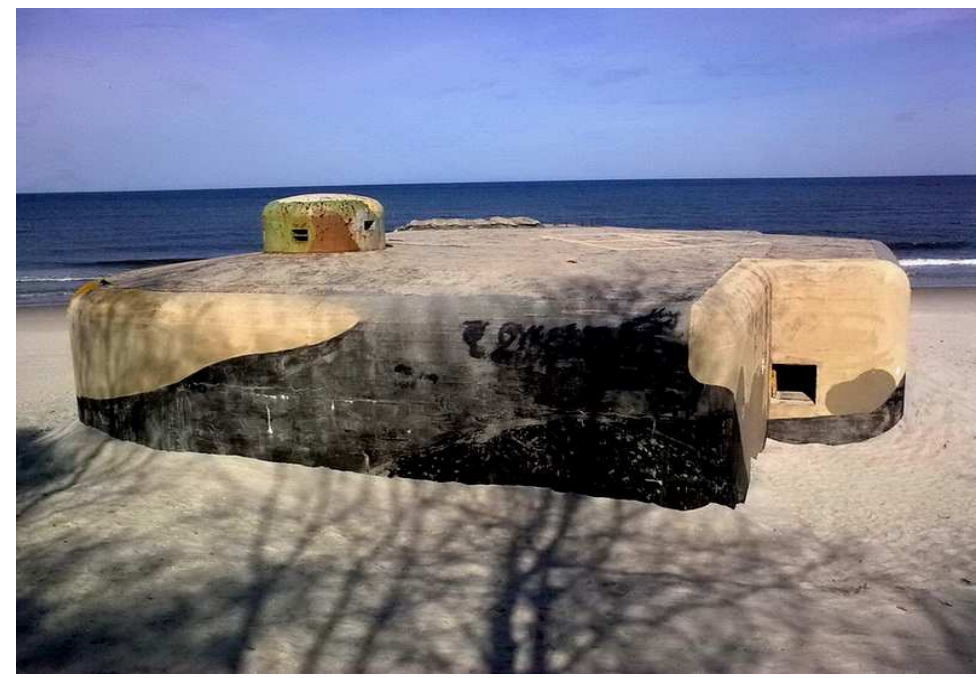

Ryc. 5. Ciężki schron bojowy Sęp w Jastarni

Źródło: fot. A. Marek

\section{Podsumowanie}

Krajobraz kulturowy Półwyspu Helskiego znacząco wpływa na podniesienie atrakcyjności turystycznej regionu. Wydarzenia historyczne z lat 30. XX w. stanowią podstawę promowania turystyki, edukacji, patriotyzmu oraz kształtowania świadomości społecznej i narodowej.

Rozwój sytuacji politycznej pod koniec XX w. (likwidacja jednostki wojskowej) przyczynił się do zwiększenia dostępności tego terenu dla odwiedzających. Dało to szansę na wyeksponowanie w krajobrazie kulturowym i wykorzystanie zapomnianych już obiektów militarnych. Dzięki staraniom miłośników historii i militariów obiekty te ocalono od zapomnienia, co poskutkowało objęciem ich ochroną prawną. Od czasu utworzenia w 2006 r. Muzeum Obrony Wybrzeża podlegają one systematycznej rewitalizacji i są zagospodarowywane jako placówki kulturowe. 


\section{Literatura}

Bernaciak A., Wiśniewska R., 2015, Możliwości turystycznego wykorzystania dawnych obiektów militarnych pótnocnego odcinka Międzyrzeckiego Rejonu Umocnionego, „Studia Periegetica”, 2, s. 123-135.

Chylińska D., 2006, Formy ekspozycji i udostępnienia turystycznego obiektów militarnowojskowych z czasów II wojny światowej rozwiązania polskie a praktyka europejska, „Folia Turistica”, 17, s. 77-97.

Cudny W., Rouba R., 2012, Hotelarstwo jako sposób na rewitalizację zabytkowych obiektów militarnych pochodzacych z XIX i XX wieku, „Ochrona Zabytków”, 3-4, s. 107122.

Dekret Prezydenta Rzeczypospolitej z dnia 21 sierpnia 1936 r. O uznaniu Półwyspu Helskiego za rejon umocniony, DzU z 1936 r., nr 71, poz. 512.

Godlewski P., 2013, Rozwój regionalnej turystyki militarnej (na przykładzie obiektów militarnych z okresu II wojny światowej w województwie lubuskim), „Handel Wewnętrzny: Turystyka i rekreacja czynnikami rozwoju społeczno-gospodarczego regionu", 5, II, s. 113-120.

Janeczko E., Heise M., 2013, Możliwości rozwoju turystyki militarnej w lasach na przykładzie Nadleśnictwa Wejherowo, „Studia i Materiały CEPL w Rogowie”, 15, 37 (4), s. $137-143$.

Kardas M., 2009, Gdyńskie zaślubiny Polski z morzem w 1920 roku, „Colloquium Wydziału Nauk Humanistycznych i Społecznych”, I, s. 109-116.

Kardas M., 2011, Okupacja hitlerowska Helu. Wybrane aspekty, „Zeszyty Naukowe Akademii Marynarki Wojennej”, LII, 2, s. 165-186.

Mikos von Rohrscheidt A., 2009, Polska: największe muzeum fortyfikacji na wolnym powietrzu w aspekcie rozwoju turystyki kulturowej, „Turystka Kulturowa”, 2, s. 20-48.

Miniewicz J., 1983, Konstrukcja unikalnych polskich schronów bojowych, zbudowanych w 1939 r. w Jastarni na Pólwyspie Helskim, „Kwartalnik Historii Nauki i Techniki”, 28, 1, s. 121-143.

Poczta J., 2009, Krajobraz kulturowy powojskowy Bornego Sulinowa i jego wptyw na kształtowanie polityki władz miejscowych, „Problemy Ekologii Krajobrazu”, XXV, s. 117-123.

Pszenny D., Janeczko E., 2015, Zielony Pierścień Warszawy jako obszar rozwoju turystyki militarnej, „Studia i Materiały CEPL w Rogowie”, 17, 45 (4), s. 180-186.

Sołkiewicz-Kos, Zadworny M., 2010, Rekultywacja zdegradowanych terenów powojskowych $i$ sposoby ich zagospodarowania na przykladach krajowych, „Budownictwo o Zoptymalizowanym Potencjale Energetycznym", 7, s. 271-278.

Stach E., 2013, Aktualne wykorzystanie obiektów i miejsc militarnych $w$ Polsce $w$ aspekcie militarnej turystyki kulturowej, [w:] Narębski L. (red.), Fortyfikacje nowożytne w Polsce: badania, realizacje, projekty i zagospodarowanie do wspótczesnych funkcji, Toruń, s. 213-223. 
Szarski W., 2007, Hel - nasz samotny pótwysep, „Wojsko w Społeczeństwie”, 2, s. 125130.

Wojciechowski Z., 2010, Obiekty militarne Pótwyspu Helskiego w latach 1920-2006, „Zeszyty Naukowe Akademii Marynarki Wojennej”, LI, 4, s. 247-271.

Zgłobicki W., Smyk J., Kabała A., 2016, Ocena oferty wybranych obiektów militarnych na obszarze Polski dla potrzeb turystyki dzieci i młodzieży, „Turystyka Kulturowa”, 2, s. 116-134.

\title{
Źródla internetowe
}

http://www.gohel.pl/strona-2525-fortyfikacje_cypla_helskiego.html (29.11.2017). http://www.helmuzeum.pl/muzeum/historia-mow\#mow (28.11.2017).

\section{Military objects as an element of the cultural landscape of the Hel Peninsula}

\section{Summary}

The aim of this paper is to present the military objects of the Hel Peninsula which played a key role during the defense of September 1939. What has served as an object of this research is the two regions of the Hel Peninsula, in the landscape of which many fortifications have survived, namely, The Jastarnia Resistance Center and The Hel Fortified Area. The article indicates the location, military characteristics and purpose of individual elements of fortifications in both areas. These objects were later extended to cater for the needs of the army, however, they lost their rank when the military unit was disassembled. Due to the growing number of military enthusiasts The Jastarnia Resistance Center and The Hel Fortified Area had soon become a local attraction, which contributed to the revitalisation of various facilities and making them available for cultural purposes.

Keywords: Hel Peninsula, military landscape, bunkers, fortifications.

\author{
Dr Aneta Marek \\ Uniwersytet Wrocławski \\ Instytut Geografii i Rozwoju Regionalnego \\ pl. Uniwersytecki 1 \\ 50-137 Wrocław \\ e-mail: aneta.marek@uwr.edu.pl \\ Mgr Łukasz Marszałek \\ Akademia Pomorska w Słupsku \\ Instytut Geografii i Studiów Regionalnych \\ e-mail: lukasz.marszalek@apsl.edu.pl
}

